Politik Indonesia: Indonesian Political Science Review 1 (2) (2016) 154-170

Politik Indonesia

Indonesian Political Science Review

http://journal.unnes.ac.id/nju/index.php/JPI

\title{
Pilkada Serentak melalui DPRD: Sebuah Gagasan Mewujudkan Pilkada Demokratis Perspektif Pancasila dan UUD 1945
}

\author{
Mokhamad Abdul Aziz ${ }^{1 凶}$ \\ ${ }^{1}$ Universitas Islam Negeri Walisongo Semarang, Indonesia
}

\section{Info Artikel Abstrak}

Sejarah Artikel:

Diterima 31 Maret 2016

Disetujui 15 Juni 2016

Dipublikasi 15 Juli 2016

Keywords:

Simultaneous Local

Elections; Direct

Democracy; Democracy of

Pancasila

\begin{abstract}
$\overline{\text { Setelah berhasil menyelenggarakan Pilkada Serentak } 9 \text { Desember } 2015 \text { sebagai salah }}$ satu upaya penguatan demokrasi elektoral, Indonesia dihadapkan pada tantangan membangun subtansi demokrasi. Salah satu yang layak untuk dievaluasi adalah sistem Pilkada langsung oleh rakyat. Meskipun telah dilakukan secara serentak, Pilkada secara langsung masih terlalu boros, belum menghasilkan pemimpin ideal, bahkan banyak yang tersangkut kasus korupsi, dan yang paling penting tidak sejalan dengan demokrasi khas Indonesia. Pancasila mengamanatkan bahwa demokrasi Indonesia adalah demokrasi yang dipimpin oleh hikmat kebijaksanaan dalam permusyawaratanperwakilan. Inilah yang disebut demokrasi modern. Pilkada melalui DPRD secara serentak adalah solusi untuk mewujudkan Pilkada demokratis khas Indonesia.
\end{abstract}

\begin{abstract}
Unison in the succeeding organized the elections after December 9, 2015 as part of efforts to strengthen electoral democracy, Indonesia faced with the challenges of building a democratic substance. One that deserves to be evaluated is a system of direct election by the people. Although it has been conducted simultaneously, direct election is still too extravagant, yet produces the ideal leader, even a lot of them were involved in corruption cases, and most important their actions are not in line with the Indonesian democracy typical. Pancasila mandates that Indonesia's democracy is a democracy that is led by the inner wisdom of deliberations-representation. This is called modern democracy. Through Parliament elections simultaneously is the solution to realize the Indonesian democratic elections typical.
\end{abstract}

(C) 2016 Universitas Negeri Semarang

Alamat korespondensi:

ISSN $2477-8060$

Jl. Walisongo No.3-5 Semarang, Jawa Tengah, Indonesia Email: azizarf17@gmail.com 


\section{Pendahuluan}

Indonesia untuk pertama kalinya berhasil menyelenggarakan pemilihan kepala daerah dan wakil kepala daerah (Pilkada) secara serentak pada 9 Desember 2015. Hingga saat ini, isu Pilkada serentak masih menjadi perbincangan menarik di sejumlah media massa, termasuk di kalangan aktivis politik maupun intelektual pemerhati politik di kampus. Pilkada serentak mengemuka sejak ditetapkannya Peraturan Pemerintah pengganti Undang-Undang (Perppu Pilkada) menjadi Undang-Undang (UU No. 1 Tahun 2015). Belum juga dilaksanakan, UU UU No. 1 Tahun 2015 kembali diubah dalam UU No.

8 Tahun 2015, yang sebagian besar perubahannya bersifat teknis, dari mulai penyingkatan jangka waktu tahapan pilkada, penghapusan mekanisme uji publik, hingga penjadwalan ulang Pilkada Serentak.

Setelah Pilkada serentak 2015 di 269 daerah, pada tahapan selanjutnya adalah Pilkada serentak gelombang kedua pada Februari 2017 di akan dilaksanakan di 99 daerah, gelombang ketiga pada Juni 2018 di 171 daerah. Kemudian akan dilaksanakan masing-masing satu gelombang lagi sampai menuju Pilkada serentak nasional 2027. Sedemikian rupa dinamika legislasi untuk menyukseskan teknis pelaksanaan demokrasi di tingkat lokal ini menekankan pada efisiensi penyelenggaraan Pilkada serentak. Namun, patut menjadi catatan bahwa fokus teknis dan efisiensi Pilkada saat ini tidak boleh melupakan tujuan utama Pilkada yaitu mendapatkan kepala daerah yang berkualitas. Tidak ada yang menjamin bahwa Pilkada yang efisien dengan teknis yang sedemikian rupa berimplikasi kepada kualitas penyelenggaraan pemerintah daerah selama kepala daerah menjabag sebagai kepala daerah.

Namun demikian, keberhasilan KPU menyelenggarakan Pilkada serentak pada 9 Desember 2015 patut diapresiasi sebagai bagian dari penguatan demokrasi prosedural. Pilkada serentak harus terus ditingkatkan kualitasnya sampai kepada cita-cita ideal demokrasi lokal. Sedangkan, kualitas penyelenggaraan pemerintah daerah, yang sangat dipengaruhi oleh kualitas dan kapabilitas seorang kepala daerah, tentu menjadi persoalan lain yang harus juga diselesaikan. Sudah banyak tulisan yang berisikan evaluasi terhadap kinerja kepala daerah terkait dengan berkaitan dengan Pilkada. Ditemukan banyak kepala daerah yang bermasalah dengan hukum. Menteri Dalam Negeri (Mendagri) Tjahjo Kumolo menyampaikan, berdasarkan data Kemendagri, terdapat 343 kepala daerah yang berperkara dengan hukum, baik di kejaksaan, kepolisian, maupun Komisi Pemberantasan Korupsi (KPK). Sebagian besar karena tersangkut masalah pengelolaan keuangan daerah. Data ini, tentu saja, harus dijadikan bahan evaluasi terhadap hasil Pilkada yang dikatakan demokratis itu.

Salah satu penyebab utama kenapa sebagian besar kepala daerah bermasalah 
dengan hukum, terlebih berkaitan dengan kasus korupsi, adalah karena faktor "mengembalikan modal" yang dikeluarkan pada saat Pilkada. Bukan jadi rahasia lagi, jika Pilkada langsung oleh rakyat sejak 2005, sarat akan money politic. Menurut Mohammad Nasih, seorang politisi sekaligus ilmuwan politik Universitas Indonesia, Pilkada langsung selama ini lebih banyak menghasilkan pemimpin oportunis dan menyebabkan mayoritas masyarakat pragmatis. Pilpres langsung juga menghasilkan politisi yang mengandalkan pencitraan. Menurut Nasih, masyarakat masih belum siap dengan sistem pemilihan langsung, karena berbagai faktor, di antaranya pendidikan dan ekonomi.

Pilkada langsung memang menjadi dilema sampai saat ini. Di satu sisi, Pilkada langsung menunjukkan "demokrasi yang lebih demkratis" dan menjadikan kepala daerah memiliki legitimasi yang kuat karena dipilih langsung oleh rakyatnya. Akan tetapi, di sisi lain harus diakui bahwa hasil dari pilkada langsung tidak lebih baik dari sebelumnya. Ini menjadikan bangsa Indonesia harus berpikir kebelakang, menyelemi apa maksud dan citacita founding fathers Indonesia dalam mengonstruk Pancasila dan UUD 1945 sebagai dasar negara dan konstitusi Indonesia. Saat ini, kita "dininabobokkan" oleh penyataan bahwa Indonesia merupakan negara demokrasi terbesar ketiga di dunia. Kondisi demikian memang menjadi nilai lebih bagi Indonesia dalam pergaulan internasional yang hampir semua negara memperjuangkan demokrasi. Namun, pujian dan label itu tidak lantas melupakan cita-cita awal bangsa Indonesia untuk menjadikan negara-bangsa yang berdaulat, adil, dan makmur.

Dalam bingkai dan perspektif itulah, makalah ini ditulis, untuk menemukan kembali demokrasi yang ideal, yang sesuai dengan jadi diri bangsa Indonesia, dalam konteks kedaerahan (baca: lokal). Bagaimana sejatinya Pancasila dan UUD 1945 menghendaki demokrasi di Indonesia, terutama demokrasi lokal yang sampai saat ini masih menjadi perdebatan dan memunculkan banyak problem.

\section{Temuan dan Diskusi}

\section{Hakikat Demokrasi}

Istilah demokrasi yang khas sejarah masyarakat Barat hingga kini masih diyakini sebagai konsep medern yang cocok bagi masyarakat modern. Hampir-hampir bagi negara di dunia yang ingin dianggap atau berusaha mengidentifikasi dirinya sebagai negara modern tidak ada yang menolak konsep demokrasi. Yang terjadi justru bagi negara-negara yang otoriter maupun sentralistik berusaha mengidentifikasi dirinya sebagai negara demokrasi (Fatwa, 2003). Karena itu, demokrasi seolah menjadi harga mati untuk dijadikan sebagai sistem dan bentuk di dalam sebuah negara. Namun, tentu saja tidak dapat dihilangkan kemungkinan demokrasi justru berdampak buruk kepada 
negara yang "menganut" dan
menjalankannya.
Secara etimologis, demokrasi berasal
dari kata Yunani demos berarti rakyat, dan
kratos/kratein berarti kekuasaan/berkuasa.
Demokrasi berarti rakyat berkuasa atau
government by the people (Budiarjo, 2008).

Bagi Jimly Asshiddiqie, demokrasi pertamatama merupakan gagasan yang mengandaikan bahwa kekuasaaan itu adalah dari, oleh, dan untuk rakyat. Dalam pengertian yang lebih partisipatif, demokrasi itu bahkan disebut sebagai konsep kekuasaan dari, oleh, untuk dan bersama rakyat. Artinya, kekuasaan itu pada pokoknya diakui berasal dari rakyat, dan karena itu rakyatlah yang sebenarnya menentukan dan memberi arah serta yang sesungguhnya menyelenggarakan kehidupan kenegaraan (Asshiddiqie, 2006). Dalam bahasa UUD NRI 1945, subtansi demokrasi bisa ditemukan pada frase "kedaulatan tertinggi berada di tangan rakyat".

Bertalian dengan negara, Moh. Mahfud MD, dengan mengutip pendapat Amirmachmud, mengemukakan bahwa negara demokrasi adalah negara yang diselenggarakan berdasarkan kehendak dan kemauan rakyat, atau jika ditinjau dari sudut organisasi ia berarti suatu pengorganisasian negara yang dilakukan oleh rakyat sendiri atau atas persetujuan rakyat karena kedaulatan berada di tangan rakyat (Mahfud, MD, 2003). Bagi Robert A. Dahl, ada beberapa kriteria berlangsungnya proses demokrasi dalam suatu negara, yaitu partisipasi yang efektif, persamaan dalam memberikan suara, mendapatkan pemahaman yang jernih, melaksanakan pengawasan akhir terhadap agenda, dan pencakupan orang dewasa (Dahl, 2001).

$\begin{array}{rccc}\text { Lyman } & \text { Tower } & \text { Sargent } & \text { (1981) } \\ \text { mengemukakan } & \text { bahwa } & \text { suatu } & \text { negara }\end{array}$
demokrasi mesti memenuhi beberapa unsur:

a. Warga negara terlibat dalam pembuatan keputusan publik.

b. Adanya persamaan sampai tingkat tertentu di antara warga negara.

c. Adanya jaminan kebebasan dan kemerdekaan bagi warga Negara.

d. Adanya sistem perwakilan.

e. Supremasi hukum.

f. Adanya aturan sistem perwakilan mayoritas.

g. Pendidikan.

Sedangkan Robert A. Dahl, sebagaimana dikutip oleh Arend Lijphart, mengemukakan bahwa secara umum, ada delapan jaminan kelembagaan dalam sebuah negara demokrasi, yaitu:

a. Kebebasan untuk membentuk dan bergabung dalam organisasi.

b. Kebebasan untuk berpendapat

c. Hak untuk memilih.

d. Hak untuk dipilih dalam jabatanjabatan publik.

e. Hak dari pemimpin politik untuk bersaing dalam mendapatkan dukungan dan suara.

f. Tersedianya sumber-sumber informasi alternatif. 
g. Pemilihan yang bebas dan jujur.

h. Tersedianya lembaga-lembaga untuk menjadikan kebijakan-kebijakan pemerintah tergantung pada suara dan lain-lain pendapat yang disukai seseorang (Lijphart, 1991).

Para pakar mendikotomikan demokrasi menjadi dua; (1) bentuknya yang prosedural; dan (2) dalam formula substansi. Demokrasi prosedural lebih mengutamakan pada bentuk dan prosedur yang disepakati secara hukum dan politis, sedangkan jenis yang lain lebih berpegang pada substansi, pada isi. Demokrasi prosedural mencukupkan diri pada perolehan suara terbanyak, asal prosedurnya ditaati. Inilah mekanisme voting dalam skala besar, tentang rakyat yang memilih pemimpinnya. Bahwa dikatakan demokratis adalah siapa saja yang dapat memperoleh voting terbanyak dari rakyat. Bahwa demokrasi itu hampir sama derajatnya dengan negara itu sendiri. Kalau ada kredo "NKRI harga mati", maka demokrasi itumeminjam istilah kitab suci-sebagai "laa roiba fiih". Tidak ada keraguan di dalamnya. Kebenaran demokrasi dipandang sebagai kebenaran yang mutlak dan tidak terbantahkan. ${ }^{67}$

Karena itu, bagi sebagian besar ilmuwan politik dunia, demokrasi dikatakan sebagai sistem terbaik dan sempurna. Meski demikian, ada yang menyatakan bahwa demokrasi tetap memiliki celah kelemahan

67 Fathoni, "Kabut Asap Panitia Pesta Demokrasi", makalah diakses dari https://www.academia.edu/ 7803279/Pemilu_Serentak_dan_Permasalahannya, h. 5 dan kekurangan, sehingga muncullah pernyataan bahwa demokrasi adalah sistem terbaik di antara yang tidak baik. Bagi penentang demokrasi, tentu tidak perlu dijelaskan bagaimana pernyataan dan sikap mereka. Memang perdebatan mengenai demokrasi ini, terletak konflik yang sangat tajam dalam sejarah teori demokrasi; apakah demokrasi harus berarti suatu jenis kekuasaan rakyat (suatu bentuk politik di mana warga negara terlibat aktif dalam pemerintahan dan pengaturan sendiri atau suatu bantuan bagi pembuatan keputusan (suatu cara pemberian kekuasaan kepada pemerintah melalui pemberian suara secara periodik). Dari konflik tersebut, David Held menjelaskan bahwa ada tiga jenis atau model pokok demokrasi (Held, 2004). Pertama, demokrasi langsung atau demokrasi partisipasi, suatu sistem pengambilan keputusan mengenai masalahmasalah publik di mana warga negara terlibat secara langsung. Ini adalah tipe demokrasi "asli" yang terdapat di Atena Kuno. Oleh karena itu, Mohammad Nasih menyebut demokrasi langsung sebagai demokrasi paling kuno dalam sejarah dunia.

Kedua, demokrasi liberal atau demokrasi perwakilan, suatu sistem pemerintahan yang mencakup "pejabatpejabat" terpilih yang melaksanakan tugas mewakili kepentingan atau pandangan dari para warga negara dalam daerah yang terbatas, sambil tetap menjunjung tinggi aturan hukum. Robert A. Dahl dalam buku Democracy and Its Critics menjelaskan 
bahwa demokrasi perwakilan adalah demokrasi yang dibuat menjadi praktis untuk jangka waktu lama dan mencakup wilayah yang amat luas. Pada 1820, James Mill menyatakan, system perwakilan sebagai penemuan besar di masa-masa modern di mana penyelesaian segala kesukaran, yang bersifat pemikiran maupun praktis, mungkin akan ditemukan (Dahl, 1992).

Ketiga, demokrasi yang didasarkan atas model satu partai (meskipun sementara orang mungkin meragukan apakah hal ini merupakan suatu bentuk demokrasi juga). Dalam perjalanan bangsa Indonesia, ketiga model demokrasi ini menjadi "dialektika negara" di kalangan ilmuwan dan politisi untuk diterapkan dalam konteks negarabangsa yang kaya akan sumber daya ini.

\section{Demokratisasi di Indonesia}

Beranjak dari beberapa uraian tentang hakekat dan kriteria negara demokrasi di atas, tampak bahwa penyelenggaraan pemilihan umum untuk memilih para wakil rakyat yang duduk di parlemen maupun memilih pejabat tertentu yang duduk di lingkungan pemerintahan merupakan salah satu syarat berlangsungnya demokratisasi dalam kehidupan bernegara. Pemilihan umum sejatinya merupakan salah satu sarana untuk mewujudkan kedaulatan rakyat dalam kehidupan kenegaraan. Dengan pemilihan yang bersifat umum dan berkesamaan, Deliar Noer, saat menjelaskan pemikiran Karl Kautsky mengenai sosialisme demokrasi, menyatakan bahwa demokrasi adalah cara mengubah perjuangan kelas dari perkelahian fisik menjadi perjuangan atas intelejensi dalam mana suatu kelas tertentu akan menang, hanya bila ia secara intelektual dan moral memang sejajar dengan lawannya. Demokrasi adalah cara satu-satunya untuk merealisir bentuk yang lebih tinggi dari kehidupan, bentu yang oleh sosialisme diakui sebagai hak dari orang-orang yang beradab (Noer, 2003).

Demokrasi sebagai harga mati dalam pola perekrutan pemimpin negara memang tidak dapat dihindari. Negara yang dipandang tidak demokratis akan dicibir sebagai negara yang tidak beradab. Dalam konteks Indonesia, "suksesi kepemimpinan" untuk mendapatkan hak setiap individu relatif berhasil, meskipun pada 1998 harus diwarnai dengan pertumpahan darah antara para demonstran dengan TNI-Polri. Peristiwa reformasi 1998 tersebut adalah upaya meluruskan demokrasi yang selama masa Orde Baru hanya berupa nama dan prosedur formalitas. Akhirnya, demokrasi dikatakan lahir kembali pasca peristiwa itu. Para "pemuja" demokrasi menyatakan bahwa Indonesia, sejak awal pendiriannya oleh the founding fathers, memang dikehendaki sebagai sebuah negara demokrasi. Hal itu tercermin dari pemaknaan terhadap sila ke 4 Pancasila, rumusan alinea keempat Pembukaan UUD 1945, dan Pasal 1 ayat (2) UUD 1945. Karena itu, demokrasi menjadi sistem yang final bagi Indonesia untuk mewujudkan cita-cita sebagai negara yang berdaulat, adil, dan makmur. 
Diakui atau tidak, perkembangan demokrasi di Indonesia pasca kemerdekaan 1945 menunjukkan dinamika yang pasang surut. Berbagai model demokrasi dalam kehidupan bernegara telah diterapkan sebagai bagian dari try and errors dalam membumikan nilai-nilai demokrasi yang sesuai dengan sifat, karakter, ciri, dan perkembangan masyarakat Indonesia. Mulai dari Demokrasi Parlementer (1945-1959, Demokrasi Terpimpin (1959-1966), Demokrasi Pancasila ala Orde Baru (19661988), sampai Demokrasi Pancasila dalam fase Transisi (1988-sekarang), yang masingmasing memiliki kekhasan tersendiri (Fatwa, 2003). Kekhasan itu akan senantiasa berubah menyesuaikan perkembangan zaman, yang dalam konteks tertentu juga akan mengubah masyarakat Indonesia secara umum. Namun demikian, subtansi demokrasi haruslah sesuai dengan cita-cita founding fathers negarabangsa Indonesia yang tercermin dalam Pancasila sila ke-empat dan UUD NRI 1945. Demokrasi yang menempatkan rakyat sebagai pemilik kedaulatan tertinggi sering mengalami dilema ketika diterapkan dalam negara dengan jumlah penduduk besar. Melihat kenyataan penerapan demokrasi di Indonesia pasca reformasi 1998, ada banyak perkembangan dan perubahan, baik secara prosedural maupun subtansial. Presiden yang awalnya dipilih oleh MPR, pada Pemilu 2004 akhirnya dipilih langsung oleh rakyat. Pilkada yang awalnya dilakukan di DPRD, pada 2005 dipilih langsung oleh rakyat. Indonesia menjadi sorotan dunia ketika berhasil menggelar pemilu presiden secara langsung pada 2004. Susilo Bambang Yudhoyono terpilih sebagai presiden dan Jusuf Kalla sebagai wakil presiden ketika itu. Menurut Fathoni, mungkin inilah yang dinamakan sebagai demokrasi prosedural. Demokrasi dipandang cukup dalam hal prosesinya saja. Apabila legal prosedurnya, maka cukuplah demokrasi itu. Demokrasi semacam itu adalah demokrasi yang pragmatis, dalam artian demokrasi adalah perolehan suara terbanyak (demokrasi voting). Kerakyatan yang dimaknai sebagai kepemimpinan yang dijalankan dengan hikmat kebijaksanaan dalam permusyawaratan-perwakilan tidak dapat dijalankan dengan demokrasi model seperti itu. ${ }^{68}$

Padahal, subtansi demokrasi yang diamanatkan oleh Pancasila adalah demokrasi yang dipimpin oleh hikmah kebijaksanaan dalam permusyawaratan-perwakilan. Dapat dipahami bahwa demokrasi Indonesia sejatinya adalah demokrasi perwakilan. Demokrasi Pancasila dibangun atas kerakyatan. Rakyat kemudian mewakilkan kewenangannya kepada para wakil rakyat. Dalam konteks pergaulan negara modern, demokrasi perwakilan ini menjadi syarat demokrasi modern. Jikalau selama ini Indonesia dipuji sebagai negara yang demokratis, tentu saja yang dimaksud dalam hal ini adalah demokrasi prosedural, bukan

68 Fathoni, "Kabut Asap Panitia Pesta Demokrasi", makalah diakses dari https://www.academia.edu /7803279/Pemilu_Serentak_dan_Permasalahannya, h. 5 . 
demokrasi substantif yang mementingkan cita-cita dan tujuan.

Dalam konteks demokratisasi, sebenarnya Robert A. Dahl sudah menyadarkan pegiat demokrasi bahwa sistem yang dianggap terbaik ini memiliki dilema fundamental yang harus diselesaikan dalam masing-masing negara, sesuai dengan kekhasan dan kultur penduduknya. Apalagi berkaitan di negara yang kaya akan pluralisme. Dari enam dilema yang dijelaskan oleh Robert A. Dahl, satu di antaranya adalah sentralisasi versus desentralisasi (Dahl, 1985). Isu ini jika ditarik dalam konteks Pilkada di Indonesia, akan menimbulkan dialektika kritis yang seharusnya bersumber dari falsafah dasar demokrasi Indonesia, yang tidak lain adalah Pancasila dan UUD NRI 1945. Dan justru inilah yang membedakan demokrasi Indonesia dengan demokrasi yang diterapkan oleh bangsa-bangsa lain, sebagaimana Soekarno mengatakan: ${ }^{69}$

Oleh karena itu, bagi kita bangsa Indonesia, demokrasi atau kedaulatan rakyat mempunyai corak nasional, satu corak kepribadian kita, satu corak dus tidak perlu sama dengan corak demokrasi yang dipergunakan oleh bangsa-bangsa lain sebagai alat teknis. Artinya, demokrasi kita adalah demokrasi Indonesia, demokrasi yang disebutkan sebagai sila keempat itu adalah demokrasi Indonesia yang membawa corak kepribadian bangsa Indonesia sendiri. Tidak perlu

69 Soekarno dalam Yudi Latif, Negara Paripurna: Historisitas, Rasionalitas, dan Aktualitas Pancasila, (Jakarta: Gramedia Pustaka Utama, 2011), h. 476 "identik" artinya sama dengan demokrasi yang dijalankan oleh bangsa-bangsa lain.

Yudi Latif dalam bukunya, Negara Paripurna, menjelaskan bahwa sila keempat Pancasila "Kerakyatan yang dipimpin oleh hikmat kebijaksanaan dalam permusyawaratan perwakilan" mengandung beberapa ciri dari alam pemikiran demokrasi di Indonesia. Sedangkan dalam pembukaan UUD 1945, disebutkan bahwa kedaulatan itu berdasar atas "kerakyatan" dan "permusyawaratan". Dengan kata lain, demokrasi itu hendaknya mengandung ciri: (1) kerakyatan (daulat rakyat), dan (1) permusyawaratan (kekeluargaan). Dalam kaitannya ini, Soekarno meyakini bahwa syarat yang mutlak untuk kuatnya negara Indonesia ialah permusyawaratan perwakilan. Mohammad Hatta menambahkan bahwa kerakyatan yang dianut oleh bangsa Indonesia bukanlah kerakyatan yang mencari suara terbanyak saja, tetapi kerakyatan yang dipimpin oleh hikmat kebijaksanaan dalam permusyawarat perwakilan. Karena itu, demokrasi Indonesia bukan demokrasi liberal dan juga bukan demokrasi totaliter, karena berkaitan secara menyeluruh dengan sila-sila Pancasila lainnya (Latif, 2011).

Jelas bahwa demokrasi yang digagas oleh para pendiri bangsa Indonesia adalah demokrasi perwakilan. Sebagaimana taksonomi demokrasi oleh David Held di atas, demokrasi perwakilan yang juga disebut demokrasi modern inilah yang dicita-citakan oleh founding fathers negara-bangsa 
Indonesia. Namun, apa yang membedakan demokrasi perwakilan yang digagas Soekarno, Hatta, Yamin, dan tokoh-tokoh lainnya dengan Demokrasi Barat? As'ad Said Ali berpendapat bahwa Soekarno tidak setuju dengan Demokrasi Barat, karena demokrasi ini, misalnya, didominasi kapitalis pemilik modal, tirani mayoritas, dan sebagainya. Demokrasi model ini tidak akan mampu mewujudkan kekokohan bangsa. Oleh sebab itu, Soekarno mencari alternative bagaimana demokrasi yang dijalankan bisa mencerminkan "kebersamaan" dan "keadilan sosial", dua istilah yang perlu digarisbawahi karena menjadi kata-kata kunci dari gagasan demokrasi yang hendak dicari (Ali, 2009).

\section{Demokrasi di Daerah}

Pilkada merupakan salah satu wujud demokrasi yang ada di daerah. Upaya mencari pemimpin daerah terbaik, sehingga bisa mewujudkan cita-cita daerah ini dilakukan dalam rangka membentuk masyarakat yang demokratis (free societies). Oleh sebab itu, demokrasi di daerah perlu mendapatkan perhatian yang memadai. Menurut Brian C. Smith, harus disadari bahwa munculnya perhatian terhadap transisi demokrasi di daerah berangkat dari suatu keyakinan bahwa adanya demokrasi di daerah merupakan prasyarat bagi munculnya demokrasi di tingkat nasional (Smith, 1998). Pendapat ini berangkat dari asumsi bahwa bahwa ketika terdapat perbaikan kualitas demokrasi di daerah, secara otomatis bisa dikatakan akan ada perbaikan kualitas demokrasi di tingkat nasional. Bisa dikatakan, jika kualitas demokrasi lokal kacau, maka bisa dipastikan, kualitas demokrasi nasional juga akan mengalami hal sama, begitu pula sebaliknya.

Larry Diamond, sebagaimana dikutip oleh Prof. Dr. Kacung Marijan, mengemukakan beberapa alasan jika pemerintah daerah, termasuk DPRD, memiliki peran penting untuk mempercepat vitalitas demokrasi. Pertama, pemerintah daerah dapat membantu mengembangkan nilai-nilai dan keterampilan berdemokrasi di kalangan warganya. Kedua, pemerintah daerah dapat meningkatkan akuntabilitas dan pertanggungjawaban kepada berbagai kepentingan yang ada di daerah. Ketiga, pemerintah daerah dapat menyediakan saluran dan akses tambahan terhadap kelompokkelompok yang secara historis termarginalisasi. Ketika hal ini dipenuhi, terdapat kecenderungan adanya tingkat keterwakilan demokrasi yang lebih baik. Keempat, pemerintah daerah bisa memberikan kesempatan kepada partai-partai atau fraksifraksi untuk melakukan oposisi di dalam kekuasaan politik (Marijan, 2011). Alasanalasan tersebut menunjukkan betapa pentingnya penguatan demokratisasi yang ada di daerah, guna mendorong kualitas demokrasi nasional yang bertabat.

Untuk mempercepat proses transformasi menuju demokrasi di daerah, ada beberapa hal yang harus dilakukan, di antaranya adalah memperkuat sistem 
perwakilan, meningkatkan kemampuan pemerintah daerah, dan diperlukan adanya budaya politik serta civil society yang mendukung. Sedangkan untuk membangun sistem pemerintahan yang demokratis di daerah dibutuhkan sistem perwakilan yang terbangun oleh sistem pemilu di daerah juga. Pemerintah daerah, misalnya, harus bertanggung jawab terhadap lembaga yang dipilih melalui pemilu. Misalnya saja, kepala daerah yang harus mempertanggungjawabkan pemerintahan yang dipimpinnya kepada DPRD, suatu lembaga perwakilan yang dipilih melalui pemilu. Proses kelembagaan ini sebenarnya telah terlihat pada penguatan DPRD periode 1999-2004. Sebelumnya, DPRD lebih berfungsi sebagai penopang kebijakan-kebijakan eksekutif dan pemerintah pusat. Padahal, DPRD yang merupakan bagian dari lembaga legislatif tentu memiliki peran dan fungsi yang berbeda dengan pemerintah sebagai badan eksekutif di daerah. Adanya pertanggungjawaban seperti itu tidak hanya akan menjadikan pemerintahan di daerah lebih akuntabel dan transparan, tetapi juga demi membangun system perwakilan yang lebih baik. Ketika DPRD dipilih secara demokratis, pertanggungjawaban kepala daerah kepada DPRD bisa dimaknai sebagai bentuk pertanggungjawaban kepada wakil rakyat yang mewakili kepentingankepentingan rakyat. Namun, upaya ini ternyata tidak berjalan mulus, sebagaimana yang dibayangkan. Kepala daerah yang dipilih oleh DPRD dan bertanggungjawab kepada
DPRD sebagai perwakilan rakyat tidak mempercepat proses demokratisasidi daerah. Sampai pada akhirnya, muncullah kebijakan penyelenggaraan Pilkada secara langsung. Upaya kelembagaan baru ini diharapkan mampu mempercepat demokratisasi di daerah, di samping karena realitas empiris tentang adanya perilaku negatif oleh sebagian anggota DPRD pada 1999-2004.

Persoalan yang kini harus dijawab adalah bagaimana proses demokratisasi di daerah pasca Pilkada secara langsung, apakah lebih baik atau sebaliknya. Secara ideal Pilkada langsung sebagai proses yang diciptakan dalam sistem demokrasi langsung di Indonesia seharusnya dapat memberikan implikai positif atas harapan akan terwujudnya kehidupan dan pengelolaan pemerintahan yang kompeten dan kapabel, sehingga tidak hanya menjadi ruang formalitas pergantian kepemimpinan secara simbolik semata sehingga berubah makna menjadi sebuah proses demokrasi semu (pseudo democracy). Apa jadinya jika sebuah negara atau daerah hanya menikmati demokrasi prosedural yang seoalah-olah baik dan maju, tetapi secara subtansi cacat, dan bahkan tidak menunjukkan perbaikan sama sekali. Tentu saja hal ini perlu dievaluasi.

Menurut M. Nur Alamsyah dalam penelitiannya, telah terjadi fenomena Electocracy dalam Pilkada Langsung di Indonesia. Hal merujuk pada kenyataan yang diperoleh bahwa banyak pemimpin daerah yang terpilih hanya karena hasrat berkuasa 
dan luasnya jaringan popularitas bukan karena kompetensi dampaknya terlihat pada sistem manajemen pemerintahan yang bobrok sehingga paradigma yang hendak dicapai yang seharusnya menuju kepada praktik good governance bergeser menjadi bad governance. Tidak lahirnya civil society yang diharapkan dapat menjadi instrumen kuat terhadap hegemoni atas berbagai kepentingan hidup masyarakat oleh pemerintah melalui berbagai antek-antek yang dibagunnya bersama dengan para kapitalis sebagai mekanisme rent seeking, menjadikan keterpurukan nilai demokrasi kembali pada posisi sebatas prosedur semata (Alamsyah, 2012).

Rendahnya kualitas pemimpin daerah ataupun nasional di alam demokrasi tentu menjadi persoalan yang tidak boleh dibiarkan. Karena bagaimanapun, sistem demokrasi yang dianggap sebagai sistem pemerintahan terbaik saat ini harus berbanding lurus dengan kualitas pemimpin yang terbaik pula. Dalam konteks ini, Mohammad Nasih memberi catatan terhadap proses penerapan demokrasi di Indonesia yang hubungannya dengan media massa. Menurutnya, jika demokrasi diterapkan dalam negara yang besar, yang muncul adalah calon-calon yang memoles diri untuk membuat kepalsuan menjadi seolaholah asli. Masyarakat akan mengalami kesulitan besar untuk mengidentifikasi apakah figur yang muncul adalah asli atau palsu. Inilah kerumitan yang selama ini diabaikan oleh para teoritikus juga pelaku politik. Perlu dicatat bahwa di negara yang sebesar polispolis di Yunani, yang penduduknya hanya sekitar 60.000-an pun, banyak filsuf yang menolak demokrasi. Di antara alasan yang mereka ajukan adalah demokrasi hanya akan menjadikan para badut sebagai pemimpin politik. $^{70}$

Jika dibiarkan, tentu hal ini tampak paradoks dengan tujuan demokrasi itu sendiri, apalagi terhadap demokrasi lokal. Sebab, di era otonomi daerah, rakyat di daerah menghendaki agar calon gubernur/wakil gubernur, bupati/wakil bupati, dan walikota/wakil walikota, merupakan sosok pribadi yang memiliki kemampuan ideal dalam banyak hal (Ali, 2003). Dengan perkataan lain, pemimpin daerah menjadi tumpuan utama pembangunan di daerah agar bisa mencapai masyarakay adil dan makmur. Oleh sebab itu, demokrasi harus menghasilkan pemimpin yang diharapkan tersebut.

\section{Pemilihan Kepada Daerah Secara Serentak yang Demokratis Menurut Pancasila dan UUD NKRI 1945}

Indonesia telah memulai tonggak baru pembangunan demokrasi, yaitu pemilihan kepala daerah (Pilkada) dilakukan secara serentak. Ketua Komisi Pemilihan Umum (KPU) Husni Kamil Manik mengatakan, sesuai dengan Undang-Undang Nomor 8 Tahun 2015, Pilkada serentak dilakukan bertahap. Yakni tahap pertama pada 9

${ }^{70}$ Mohammad Nasih, "Demokrasi dan Defisit Pemimpin Autentik", (Koran Sindo, 3 Oktober 2015), h. 6 
Desember 2015, tahap kedua Februari 2017, tahap ketiga pada Juni 2018, tahap keempat tahun 2020, tahap kelima tahun 2022, dan tahap kelima tahun 2023. Jika semua tahapan itu berjalan tanpa hambatan dan sesuai rencana, Pilkada serentak secara nasional baru bisa dilaksanakan pada tahun $2027 .^{71}$ Ini merupakan terobosan penting yang dilakukan pemerintah dalam mengupayakan Pilkada sebagai momentum untuk memilih kepala daerah secara terorganisir dan terstruktur dengan mempertimbangkan efisiensi. Ini merupakan langkah politik pemerintah yang patut mendapatkan apresiasi. Karena inilah untuk pertama kalinya dalam sejarah Indonesia, model pemilihan kepala daerah secara serentak diberlakukan secara masif dan bersamaan.

Namun demikian, meski secara teknis Pilkada serentak menjadi penanda majunya demokrasi elektoral di Indonesia, dari segi substansi, kualitas demokrasi masih perlu dipertanyakan. Sebagai praktik baru dalam demokrasi lokal di Indonesia, pelaksanaan Pilkada serentak sejatinya membuka peluang untuk meningkatkan kualitas demokrasi di Indonesia. Pilkada akan menjadi penentu nasib rakyat selama lima tahun ke depan, sehingga yang diharapkan rakyat dalam Pilkada adalah lahirnya pemimpin terbaik yang akan membawa kemajuan peradaban daerah. Karena itu, Pilkada haruslah

${ }^{71}$ Husni Kamil Manik, "Ketua KPU: Pilkada Serentak, Sejarah Sekaligus Tantangan", Lihat: http://news. liputan6.com/read/2244960/ketua-kpu-pilkada-serentaksejarah-sekaligus-tantangan (Diakses 22 Maret 2015). dilaksanakan secara demokratis, jujur, dan adil.

Sejak tahun 2005, pemilihan kepala daerah dilakukan secara langsung. Praktik ini didasarkan pada ketentuan UU No. 32 Tahun 2004 dengan berlandaskan pada ketentuan Pasal 18 ayat (4) UUD 1945 yang menentukan bahwa Gubernur, Bupati, dan Walikota masing-masing sebagai kepala pemerintahan daerah provinsi, kabupaten, dan kota dipilih secara demokratis. Apabila dicermati, sesunggunnya ketentuan Pasal 18 ayat (4) UUD 1945 tersebut tidak menegaskan keharusan bahwa Gubernur, Bupati dan Walikota harus dipilih melalui suatu pemilihan yang dilaksanakan secara langsung. Akan tetapi, menurut Rozali Abdullah, oleh karena Daerah merupakan bagian tak terpisahkan dari Negara Republik Indonesia, maka dalam melakukan pemilihan kepala daerah dan wakil kepala daerah seharusnya sinkron dengan pemilihan presiden dan wakil presiden, yaitu melalui pemilihan langsung (Abdullah, 2005).

Setelah proses percepatan demokrasi secara beruntun tersebut berjalan lebih lima dari 10 tahun terhitung dari 1 Juni 2005, ternyata masih juga menyisakan banyak persoalan, bahkan agenda pemilihan kepala daerah secara langsung pun juga berkontribusi menambah beban politik, social, bahkan beban finansial republik ini. Pemilihan kepala daerah secara langsung terlalu boros, dan tidak seimbang dengan cost politik yang telah dikorbankannya. Kenyataan yang tak 
terhindarkan dalam pemilihan kepala daerah secara langsung adalah muncul kapitalisasi dalam tahapan pemilihan kepala daerah. Dengan munculnya kapitalisasi ini maka pemilihan kepala daerah secara langsung jauh lebih mahal dibandingkan dengan model pemilihan kepala daerah lewat perwakilan DPRD (Amirudin dan Bisri, 2006).

Dalam pelaksanaan pemilihan kepala daerah secara langsung selama ini, nuansa yang paling menonjol adalah maraknya sengketa pemilihan kepala daerah yang diajukan ke Mahkamah Konstitusi. Sidang sengketa pemilihan kepala daerah telah mendominasi perkara yang ditangani Mahkamah Konstitusi. Selain itu juga maraknya kepala daerah yang terpilih dalam pemilihan kepala daerah secara langsung banyak yang terjerat kasus korupsi dan penyelewengan wewenang lainnya. Kabar tentang kepala daerah yang tersandung kasus korupsi tak pernah berhenti mengalir. Pemilihan kepala daerah secara langsung dalam era liberalisasi politik dengan kekuatan partai politik yang dominan, memungkinkan sekali yang bias bertempur di sana adalah mereka yang memiliki capital ekonomi dan politik yang kuat.

Para pengusaha yang dekat dengan partai politik atau para incumbent yang kaya adalah yang paling besar mendapatkan peluang masuk dalam bursa pencalonan dalam pemilihan kepala daerah. Atas dasar kemampuan financial dan kekuatan kapital ekonomi ini, maka yang dapat masuk dalam bursa kepemimpinan daerah bukanlah figurfigur yang berkompeten yang memiliki kapabilitas yang baik, akan tetapi hanya mereka yang termasuk dalam kelompok orang kaya atau memiliki kemampuan finansial yang kuat. Lalu bagiamana dengan cita-cita rakyat nantinya? Apakah mereka akan menyerahkan kekuasaan kepada yang bukan ahlinya. Tentu saja ini menjadi persoalan yang serius yang harus diselesaikan.

Tidak hanya soal figur yang masuk lebih banyak yang tidak berkualitas, Mahkamah Konstitusi (MK) juga mencatat, sejak Pilkada dilakukan secara langsung, sangat banyak jumlahnya sengketa Pilkada yang diajukan MK. Untuk Pilkada serentak yang dilaksanakan 9 Desember 2015 lalu, dari 264 daerah yang menyelenggarakan Pilkada, sebanyak 144 permohonan sengketa Pilkada masuk di MK. ${ }^{72}$ Ini mengindikasikan terdapat banyak kecurangan dan ketidakjujuran dalam Pilkada langsung. Anthony Giddens dalam buku "The Third Way and Its Critiques" menyatakan bahwa sebagian besar dari masyarakat demokratik baru hanya mengalami perubahan secara superfisialmereka tetap disetir oleh oligarkiyang egois. Ada banyak negara yang secaraformal menjadi demokratik, tetapi seringkali sangat korup dan pemilihan yang berlangsung dimanipulasi (Giddens, 2003). Indonesia saat ini mungkin masuk dalam kategori itu. Lantas,

72 Lihat http://www.mahkamahkonstitusi.go.id/index .php?page=web.Berita\&id=12629\#.Vvy1YOJ9600 (Diakses 22 Maret 2016). 
demokrasi langsung apakah akan tetap dipertahankan?

Pasal 18 ayat (4) UUD 1945 sebagai dasar konstitusional pelaksanaan pemilihan kepala daerah, sesungguhnya lahir bersamaan dengan Pasal 18A dan Pasal 18B, yaitu pada perubahan kedua UUD 1945 dan dimasukkan dalam Bab tentang Pemerintahan Daerah. Selanjutnya Pasal 22E lahir melalui perubahan ketiga UUD 1945 tetapi tidak memasukkan Pasal 18 ayat (4) melainkan hanya ketentuan Pasal 18 ayat (3) yang mengatur mengenai DPRD. Hal ini, menurut Leo Agustina, setidaknya dapat diartikan bahwa Konstitusi tidak hendak memasukkan pemilihan kepala daerah dalam pengertian pemilihan umum sebagaimana dimaksud dalam Pasal 22E ayat (1) yang menyebutkan "pemilihan umum dilaksanakan secara langsung, umum, bebas, rahasia, jujur, dan adil setiap lima tahun sekali” (Agustino, 2009).

Meskipun pemilihan secara langsung dipandang memiliki makna positif dari aspek legitimasi dan kompetensi, frase "dipilih secara demokratis" sebagaimana dimaksud Pasal 18 ayat (4) UUD 1945 tidak dapat diterjemahkan secara tunggal sebagai pemilihan secara langsung. Pemilihan secara tidak langsung atau perwakilan pun dapat diartikan sebagai pemilihan yang demokratis, sepanjang proses pemilihan yang dilakukan demokratis. Sebab, DPRD sebagai wakil rakyat telah dipilih langsung oleh rakyat, yang artinya sudah mendapatkan mandat dari rakyat untuk mewakili masingnya untuk menjalankan tugas tersebut. Menurut Jimly Asshiddiqie perkataan "dipilih secara demokratis" bersifat luwes, sehingga mencakup pengertian pemilihan kepala daerah langsung oleh rakyat ataupun oleh DPRD seperti yang pada umumnya sekarang dipraktekkan di daerah-daerah berdasarkan ketentuan perundang-undangan yang berlaku (Asshiddiqie, 2002).

Dalam Undang-undang Nomor 32 Tahun 2004, pemilihan kepala daerah tidak lagi dipilih melalui sistem perwakilan oleh DPRD, akan tetapi dipilih secara langsung oleh rakyat. Ini berarti pemilihan kepala daerah secara langsung memberi peluang bagi rakyat untuk ikut terlibat secara aktif dalam proses pengambilan keputusan yang sangat strategis dalam penyelenggaraan pemerintahan daerah melalui pemilihan kepala daerah secara langsung. Undangundang Nomor 32 Tahun 2004 yang mengatur tentang pemilihan kepala daerah secara langsung itu menggunakan rujukan atau konsideran Pasal 1, Pasal 18, Pasal 18A, dan Pasal 18B UUD 1945. Frase "kedaulatan di tangan rakyat" dan dipilih secara demokratis" agaknya menjadi sandaran pembuat Undangundang Nomor 32 Tahun 2004 merumuskan diterapkannya pemilihan kepala daerah secara langsung untuk menggantikan pemilihan kepala daerah melalui sistem perwakilan melalui DPRD sebagaimana diatur dalam Undang-undang Nomor 22 Tahun 1999. Akan tetapi, kata "dipilih secara demokratis" ini 
menurut Susilo dapat ditafsirkan pemilihan langsung oleh rakyat atau pemilihan melalui perwakilan oleh DPRD (Susilo, 2005).

Tentu tidak hilang dalam ingatan bangsa Indonesia, bahwa salah satu yang menyebabkan perubahan peraturan bahwa pemilihan kepala daerah tidak lagi dipilih oleh DPRD, tetapi dipilih langsung oleh rakyat adalah maraknya politik uang dan kongkalikong di DPRD saat pemilihan. Namun demikian, setelah diubah dan berjalan lebih dari 10 tahun, politik uang dan ketidakjujuran justru semakin menjadi-jadi dengan jumlah yang lebih besar dan luas. Lalu tidakkah seharusnya bangsa Indonesia mengembalikan peraturan yang dahulu dengan memperbaiki sistemnya atau menunggu dampak yang lebih besar dari proses demokrasi prosedural itu? Pancasila mengamanatkan bahwa demokrasi Indonesia adalah demokrasi yang dipimpin oleh hikmah kebijaksanaan dalam permusyawaratanperwakilan. Dengan kata lain, demokrasi yang sesuai dengan jati diri bangsa Indonesia adalah demokrasi perwakilan, demokrasi modern yang banyak dianut oleh negaranegara maju di dunia. Dalam konteks Pilkada, mengembalikan Pilkada ke DPRD dan dilakuka secara serentak se-Indonesia adalah jalan terbaik yang sesuai dengan amanah Pancasila dan UUD 1945.

\section{Kesimpulan}

Setelah berhasil menyelenggarakan pemilihan kepala daerah dan wakil kepala daerah (Pilkada) secara serentak pada 9 Desember 2015 sebagai salah satu upaya penguatan demokrasi elektoral, Indonesia dihadapkan pada tantangan membangun subtansi demokrasi yang akan mengantarkan cita-cita negara-bangsa ini ke depan. Pilkada serentak menjadi terobosan penting yang dilakukan pemerintah dalam mengupayakan Pilkada sebagai momentum untuk memilih kepala daerah secara terorganisir dan terstruktur dengan mempertimbangkan efisiensi. Ini merupakan langkah politik pemerintah yang patut mendapatkan apresiasi. Namun, evaluasi perihal jalannya demokrasi di Indonesia wajib dilakukan.

Salah satu yang layak untuk dievaluasi sistem adalah Pilkada langsung. Setelah proses percepatan demokrasi secara beruntun tersebut berjalan lebih lima dari 10 tahun terhitung dari 1 Juni 2005, ternyata masih juga menyisakan banyak persoalan, bahkan agenda pemilihan kepala daerah secara langsung pun juga berkontribusi menambah beban politik, social, bahkan beban finansial republik ini. Pemilihan kepala daerah secara langsung terlalu boros, dan tidak seimbang dengan cost politik yang telah dikorbankannya. Kenyataan yang tak terhindarkan dalam pemilihan kepala daerah secara langsung adalah muncul kapitalisasi dalam tahapan pemilihan kepala daerah. Dengan munculnya kapitalisasi ini maka pemilihan kepala daerah secara langsung jauh lebih mahal dibandingkan dengan model pemilihan kepala daerah lewat perwakilan 
DPRD. Semakin marak praktik politik uang saat Pilkada dan maraknya kepala daerah hasil Pilkada langsung terjerat kasus korupsi menjadi alarm bagi demokrasi Indonesia.

Meskipun pemilihan secara langsung dipandang memiliki makna positif dari aspek legitimasi dan kompetensi, prase "dipilih secara demokratis" sebagaimana dimaksud Pasal 18 ayat (4) UUD 1945 tidak dapat diterjemahkan secara tunggal sebagai pemilihan secara langsung. Pemilihan secara tidak langsung atau perwakilan pun dapat diartikan sebagai pemilihan yang demokratis, sepanjang proses pemilihan yang dilakukan demokratis. Sebab, DPRD sebagai wakil rakyat telah dipilih langsung oleh rakyat, yang artinya sudah mendapatkan mandat dari rakyat untuk mewakili masingnya untuk menjalankan tugas tersebut.

Pancasila mengamanatkan bahwa demokrasi Indonesia adalah demokrasi yang dipimpin oleh hikmah kebijaksanaan dalam permusyawaratan-perwakilan. Dengan kata lain, demokrasi yang sesuai dengan jati diri bangsa Indonesia adalah demokrasi perwakilan atau demokrasi liberal yang banyak dianut oleh negara-negara maju di dunia. Membiarkan demkorasi langsung, yang merupakan demokrasi paling kuno dalam sejarah, berjalan di Indonesia saat ini sama halnya membiarkan demokrasi tidak akan berdampak baik bagi bangsa Indonesia. Mengembalikan Pilkada ke DPRD dan dilakuka secara serentak se-Indonesia adalah jalan terbaik yang sesuai dengan amanah
Pancasila dan UUD 1945. Wallahu a'lam bi al-shawaab.

\section{Daftar Pustaka}

Agustino, L. (2009). Pilkada dan dinamika politik lokal. Pustaka Pelajar.

Alamsyah, M. N. (2014). Fenomena Electocracy dalam Pilkada Langsung di Indonesia. Academica, 4(1).

Ali, A. A. S. (2009). Negara Pancasila: jalan kemaslahatan berbangsa. Jakarta: LP3ES.

Ali, N. (2003). Pilkada di Era Otonomi: Berlayar Sambil Menambal Lubang di Kapal. CV Aneka Ilmu.

Amirudin, A. Zaini Bisri.(2006). Pilkada Langsung Problem dan prospek Sketsa Singkat Perjalanan Pilkada, Yogyakarta: Pustaka Pelajar.

Arend Lijphart, D. (1984). Patterns of Majoritarian and Consensus Government in Twenty-One Countries.

Budiardjo, M. (2003). Dasar-dasar ilmu politik. Gramedia pustaka utama.

Dahl, A. Robert, 1992. Demokrasi dan Para Pengkritiknya.

Dahl, R. A. (1985). Dilema demokrasi pluralis: antara otonomi dan kontrol. CV Rajawali.

Dahl, R. A. (2001). Perihal Demokrasi: Menjelajahi Teori dan Praktek Demokrasi Secara Singkat. Jakarta: Yayasan Obor Indonesia. 
Fathoni, Kabut Asap Panitia Pesta Demokrasi, makalah diakses dari https://www.academia.edu/7803279/ Pemilu_Serentak_dan_Permasalahann ya

Fatwa, A. M. (2002). Otonomi daerah dan demokratisasi bangsa. Yarsif Watampone.

Giddens, A. (2003). Jalan ketiga dan kritikkritiknya. Edisi terjemahan, dari buku The third way and its critiques, Penerjemah: Imam Khoiri. Yogyakarta: IRCiSoD.

Smith, B. C., \& Smith, B. C. (1985). Decentralization: the territorial dimension of the state (pp. 1-52). London: Allen \& Unwin.

Held, D. (2004). Demokrasi dan Tatanan Global: Dari Negara Modern hingga Pemerintahan Kosmopolitan. Terjemah: Damanhuri,(Yogyakarta: Pustaka Pelajar, 2004).

Noer, D. (1988). Islam dan Politik: Mayoritas atau Minoritas. Prisma, 5.

Jimly, A. (2006). Hukum Tata Negara dan pilar-pilar demokrasi.

Jimly, A. (2002). Konsolidasi Naskah UUD 1945 Setelah Perubahan Keempat.

Marijan, K. (2010). Sistem politik Indonesia: konsolidasi demokrasi pasca-Orde Baru. Kencana Prenada Media Group.
Sargent, L. (2008). Contemporary political ideologies: A comparative analysis. Nelson Education.

Mahfud, M. (2000). Demokrasi dan konstitusi di Indonesia. Rineka Cipta.

Abdullah, R. (2005). Pelaksanaan otonomi luas dengan pemilihan kepala daerah secara langsung. RajaGrafindo Persada.

Latif, Y. (2011). Negara paripurna: historisitas, rasionalitas, dan aktualitas Pancasila. Gramedia Pustaka Utama.

Mohammad Nasih, "Demokrasi dan Defisit Pemimpin Autentik", (Koran Sindo, 3 Oktober 2015).

Susilo, "Menyongsong Pilkada yang Demokratis", (Artikel, Jurnal Legislasi Indonesia, Vol. 2 No. 2 Juni 2005)

www.news.liputan6.com (Diakses 22 Maret 2015).

www.mahkamahkonstitusi.go.id (Diakses 22 Maret 2016)

www.nasional.kompas.com (Diakses 22 Maret 2016).

www.teropongsenayan.com, (Diakses 22 Maret 2016).Anwar, M. Syafii, Pemikiran dan Aksi Islam di Indonesia, Jakarta: Paramadina, 1995. 